\title{
Muscle-specific expression of the cardiac $\alpha$-actin gene requires MyoD1, CArG-box binding factor, and Sp1
}

\author{
Vittorio Sartorelli, Keith A. Webster, ${ }^{1}$ and Larry Kedes ${ }^{2}$ \\ Program in Molecular Biology and Genetics, Institute for Genetic Medicine, and Departments of Biochemistry and Medicine, \\ University of Southern California School of Medicine, Los Angeles, California 90033 USA
}

\begin{abstract}
Expression of the human cardiac $\alpha$-actin gene (HCA) depends on the interactions of multiple transcriptional regulators with promoter elements. We report here that the tissue-specific expression of this promoter is determined by the simultaneous interaction of at least three specific protein-DNA complexes. The myogenic determinant gene MyoD1 activated the transcription of transfected HCA-CAT promoter constructs in nonmuscle cells, including CV-1 and HeLa cells. Gel mobility-shift and footprinting assays revealed that MyoD1 specifically interacted with a single consensus core sequence, CANNTG, at -50 . Previously characterized sites interact with a protein identical with or related to the serum response factor (SRF) at -100 and Sp1 at - 70. All three elements must be intact to support transcription in muscle cells: site-specific mutation within any one of these three elements eliminated transcriptional expression by the promoter. Furthermore, expression of the promoter in embryonic Drosophila melanogaster cells that lack MyoD1 and Sp1 is strictly dependent on all three sites remaining intact and on the presence of exogenously supplied Sp1 and MyoD1. These experiments suggest that the presence of three sequence-specific binding proteins, including MyoD1, and their intact target DNA sequences are minimal requirements for muscle-specific expression of the HCA gene.
\end{abstract}

[Key Words: Transcription; MyoD1; serum response factor; Sp1; cardiac actin; muscle; differentiation]

Received March 29, 1990; revised version accepted August 3, 1990.

Transcriptional regulation requires the interaction of proteins with sequence-specific DNA elements. DNAbinding proteins may be expressed ubiquitously in eukaryotic cells, they may be restricted to a particular cell or tissue type, and their abundance or binding activity may be regulated by extracellular signals or inducers. Post-translational modifications may also contribute to regulation of the binding activity of a factor. Transcriptional activation appears to involve complex and often cooperative interactions of these factors (Andrisani et al. 1988; Davis et al. 1990; Simmons 1990; for review, see Jones 1990/ and gene expression is probably determined at least in part by the availability or activity of factors in a particular cell type and by the unique organization of the DNA target elements within the gene promoter (Guarente 1988; Ptashne 1988).

Previously, we analyzed the mechanisms governing the tissue-specific expression of the human cardiac $\alpha$ actin (HCA) gene (Minty and Kedes 1986; Miwa and Kedes 1987; Miwa et al. 1987; Gustafson et al. 1988; Gustafson and Kedes 1989). Cardiac $\alpha$-actin is the major $\alpha$-actin in adult cardiac muscle (Gunning et al. 1983), is

ICurrent address: Department of Molecular Biology, SRI International, Menlo Park, California 94025 USA.

${ }^{2}$ Corresponding author. expressed in both skeletal muscle and heart during embryogenesis (Minty et al. 1982), and is the dominant $\alpha$ actin gene expressed during differentiation of both established cell lines (Bains et al. 1984) and primary myogenic cells (Minty et al. 1986a; Gunning et al. 1987). The HCA gene promoter is expressed exclusively in myogenic cells (Minty and Kedes 1986a,b) and contains numerous nuclear protein-binding domains upstream of the TATA box (Gustafson and Kedes 1989), several of which display cooperative transcriptional activating interactions (Miwa and Kedes 1987). A promoter domain starting at $-117 \mathrm{bp}$ from the start of transcription is sufficient to convey muscle-specific expression to a heterologous reporter gene (Minty and Kedes 1986). Deletion and clustered mutagenesis analyses demonstrated that a decameric sequence at -100 bp from the transcription start site, CC $(\mathrm{AT})_{6} \mathrm{GG}$, designated as a CArG box, is required for both tissue-specific and vigorous expression from this promoter (Miwa et al. 1987). Subsequent analysis unexpectedly demonstrated that a protein that binds to this CArG box appears to be expressed in all cell types (Boxer et al. 1989a,b) and is immunologically and biochemically indistinguishable from the ubiquitously expressed serum response factor (SRF) (Boxer et al. 1989b). Furthermore, by modifying sequences between the CArG element and the TATA box we have shown 
that the HCA promoter can be activated in nonmuscle cells (Webster and Kedes 1990; T. Miwa and L. Kedes, unpubl.). In these instances, expression of the modified promoter in nonmuscle cells was still dependent on an intact CArG element. These data, along with the report of a muscle-specific protein binding to the chick skeletal $\alpha$-actin CArG box (Walsh 1989) suggested that both muscle and nonmuscle proteins can bind to the CArG box. Analogous examples are reported in the literature, including the octamer binding proteins (Tanaka and Herr 1990). An alternative possibility is that CArG boxbinding factors in the HCA gene are not tissue specific, and additional properties of the promoter are required to determine muscle-specific expression.

The recent finding that several members of a muscle determination gene family (Davis et al. 1987; Pinney et al. 1988; Braun et al. 1989; Wright et al. 1989) are able to activate the myogenic program in a variety of cells as well as promote expression of some muscle-specific genes (Weintraub et al. 1989) prompted us to investigate the role of one of those muscle determinant genes, MyoD1, in controlling the HCA gene expression. Preliminary studies (Sartorelli et al. 1989), as well as an evaluation of a chicken homolog of MyoD1, CDM1 (Lin et al. 1989), have shown that muscle determinant genes can indeed activate expression of the cognate cardiac actin gene.

Here, we report that the transcriptional regulatory activity of the complex formed by the CArG box and its binding protein(s) appears to involve additional interactions with immediately adjacent protein-DNA assemblies. To activate transcription the CArG-box complex at -100 requires the presence of the recognition sites for both the ubiquitous transcription regulatory factor Spl at -75 and the myogenic determinant, MyoD1, bound at -50 . All three DNA elements must be intact to support transcription in muscle cells: When site-specific mutation of any one of these three elements precludes binding of its sequence-specific protein, it also foils transcriptional expression of the promoter. Furthermore, expression in nonmuscle cells of transfected DNA constructs that carry the intact promoter is strictly dependent on the presence of an intact CArG box element and the presence of transcription factors Spl and MyoDl. Thus the combination of three protein-DNA complexes consisting of at least two nonmuscle-specific proteins plus a cell type-specific regulatory protein, $\mathrm{MyoD} 1$, is required for muscle-specific expression of the HCA gene.

\section{Results}

The MyoD1 protein activates transcription from the HCA promoter in nonmyogenic cell lines

Previous studies from this laboratory /Gustafson and Kedes 1989; Webster and Kedes 1990; T. Miwa and L. Kedes, unpubl.) have suggested that factors in addition to the CArG-binding factor may be involved in transcriptional activation of the HCA gene specifically in muscle cells. Because members of the MyoDl family are obvious candidates for such a role, we assayed for a trans-activation function of the HCA promoter by MyoD1. To do this we cotransfected nonmuscle cells with plasmids carrying the HCA gene promoter linked to the chloramphenicol acetyltransferase gene (HCACAT) and with plasmids that express MyoD1. Because trans-activation of the HCA-CAT transcription could arise by activation of the endogenous myogenic program of the test cells, we examined several cell lines in this way including NIH-3T3, HeLa, and Green monkey kidney cells (CV-1). Unlike a variety of other cell types including NIH-3T3, liver, fat, or nerve cells, both CV-1 and HeLa cells have proven refractory to MyoD1-induced myogenic conversion (Weintraub et al. 1989). The results of such a cotransfection experiment are presented in Figure 1. In both CV-1 and HeLa cell lines (as well as in NIH-3T3 cells, data not shown), MyoD1 trans-activated the whole HCA promoter (HCA485CAT) and the shorter construct containing the CArG element at position - 100 (HCA117-CAT) but not the HCA construct truncated at -47 (HCA47-CAT). Furthermore, the HCA construct LS6, bearing a mutated CArG box, was not trans-activated by MyoD1. A map of the DNA sequences of the HCA promoter from -26 to -118 is presented in Figure $2 \mathrm{~A}$, which also depicts the sites of protein-DNA interactions described previously (Gustafson et al. 1988; Gustafson and Kedes 1989) and in this discussion.

Expression of the ubiquitous $\beta$-actin promoter was unaffected by the presence of MyoDl, and the tissuespecific $\beta$-globin gene promoter remained repressed. Although both HeLa and CV-1 cells sustain MyoD1-driven HCA expression, HCA485-CAT expresses three- to fourfold more than HCA117-CAT in HeLa cells but at approximately the same levels in CV-1 cells. The HeLa response mimics the relative transcriptional response of these two promoter constructs in myogenic cell lines (Minty and Kedes 1986).

Optimal trans-activation occurred when $1 \mu \mathrm{g}$ of the MyoDl cDNA vector was cotransfected with $5 \mu \mathrm{g}$ of the HCA/CAT constructs (approximately a $1: 5$ molar ratio). Increasing the amount of the expression vector to $5 \mu \mathrm{g}$ (approximately a $1: 1$ ratio) inhibited transcription from both the HCA and $\beta$-actin promoters (Fig. 1). This phenomenon might be ascribed either to "transcriptional interference" (Meyer et al. 1989) or "squelching" (Gill and Ptashne 1988). This initial result suggested that MyoDl protein might physically interact with the cardiac actin gene promoter as a positively acting regulatory transcription factor and that the site $(s \mid$ of interaction were located between -117 and +68 of the gene. To test this possibility further we examined the ability of this region of the gene to physically interact with MyoDl.

The glutathione-MyoD1 fusion protein and muscle MyoD-like nuclear factors bind to the HCA promoter

DNA fragments representing segments of the HCA promoter encompassing nucleotides -485 to +68 were derived by restriction endonuclease digestion and assayed 


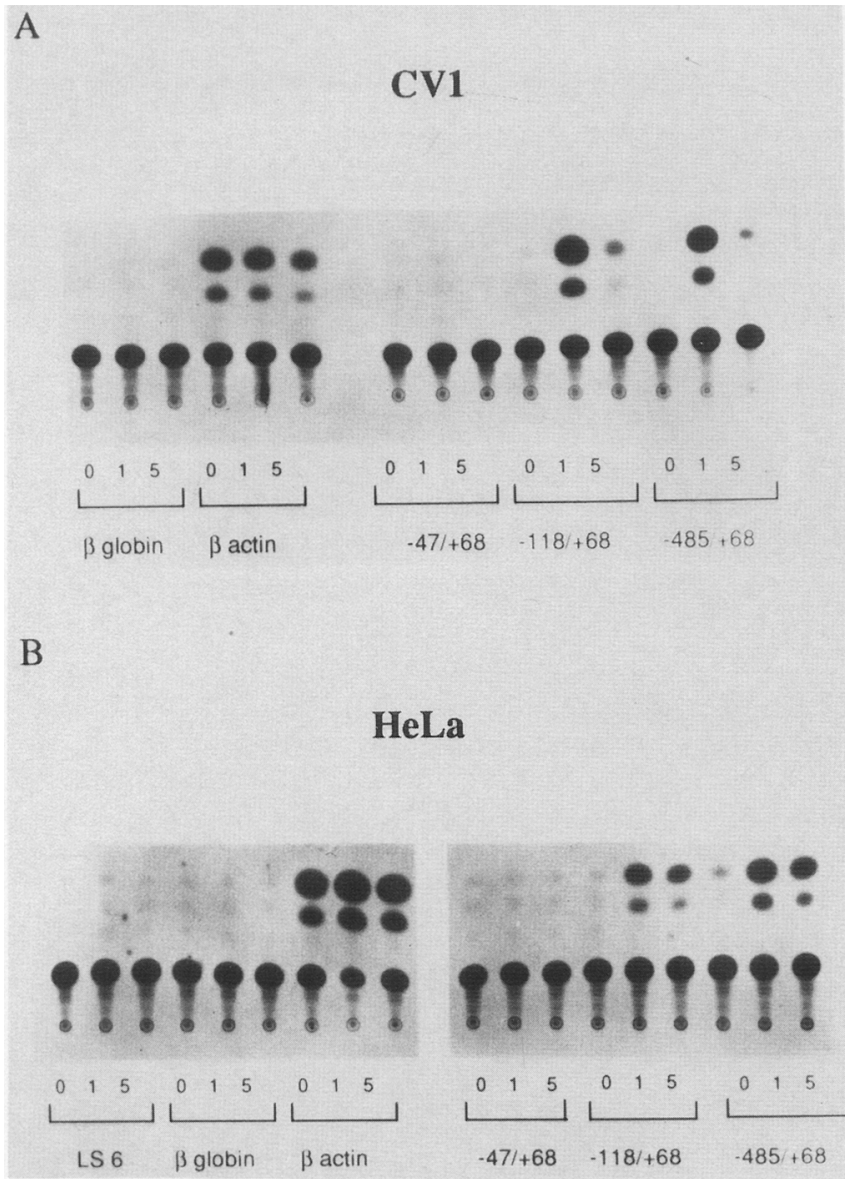

Figure 1. MyoDl activates transcription from the HCA promoter in different nonmyogenic cell lines. A constant amount $15 \mu \mathrm{g})$ of different HCA-CAT chimera constructs (pHCA485CAT, pHCAl 18CAT, and pHCA47CAT) were mixed with varying amounts of the $\mathrm{LTR}-\mathrm{MyoDl}$ expression vector and transfected into CV-l $|A|$ and HeLa $(B)$ cells. The ubiquitously expressed $\beta$-actin and the erythroid-specific $\beta$-globin CAT constructs were included as controls. The LS6 construct has a mutated CArG box at -100 (see Fig. 2). (0, 1, and 5) $\mathrm{Mi}^{-}$ crogram amounts of the LTR-MyoDl expression vector used in each experiment. After transfection, the cells were cultured for $48 \mathrm{hr}$ and the determination of CAT activity was performed as described in Methods. The figure is an autoradiograph of thin-layer chromatographic plates after separation of the acetylated and nonacetylated forms of ${ }^{14} \mathrm{C}$-chloramphenicol.

for interaction with a bacterially produced glutathioneMyoDl fusion protein by gel electrophoretic mobilityshift (GEMS) assays. A DNA fragment representing nucleotides $-70 /+68$ of the gene bound the MyoDl fusion protein (Fig. 3A, lane 1) but the glutathione-S-transferase protein itself did not bind (data not shown). The specificity of this interaction was challenged by adding different DNA fragments spanning the HCA promoter. A 100-fold molar excess of nonlabeled $-70 /+68$ or $-127 /-47$ fragment competed for the MyoDl binding (lanes 2 and 3), whereas the remaining promoter fragments (lanes 4 and 5) used at the same molar excess failed to prevent the interaction. Furthermore, incuba- tion of the glutathione-MyoDl protein with HCA DNA fragment $-47 /+68$ did not result in any specific shifted bands in the GEMS assay (lanes 6) and did not compete for binding (data not shown). We conclude that a binding site for MyoDI appears to lie between -70 and -47 of the HCA promoter. We sought to verify that a muscle cell nuclear factor interacts with the same HCA DNA sequence recognized by the glutathione-MyoDl fusion protein. $\mathrm{C} 2$ and HeLa cell nuclear extracts were tested for the presence of DNA-binding proteins that would interact with the $-70 /-40$ DNA element of the HCA gene. The data presented in Figure 3B demonstrate that several major protein-DNA complexes (right-hand symbols in Fig. 3B) are observed with $\mathrm{C} 2$ cell nuclear extracts (lane 5). The intensity of the binding of the bands indicated by filled circles is diminished in the presence of excess unlabeled probe (lane 6). The bands with faster mobility (indicated by the bracket) were variably affected and appear to be nonspecific. A mutant oligonucleotide $(\mu \sigma$, see Fig. $2 \mathrm{~A})$ does not compete for any of the complexes (data not shown). A different and less complex banding pattern was seen with HeLa cell nuclear extracts (open circle, left side of Fig. 3B) and this DNA-protein complex (lane 1) appears unaffected by the presence of an excess of unlabeled probe (lane 2). We used monoclonal antibodies directed against the MyoD amino acid residues 66-99 of a trpE-MyoDl fusion protein to test whether the DNA-protein complexes that we observed represented interactions with proteins antigenically related to MyoDl. The monoclonal antibody, $\alpha M y o D 1$, as well as a second monoclonal antibody $(6 \mathrm{~F} 1)$, directed against the bovine histone 1 protein, which was used as a control serum, were generously provided by Stave Kohtz (Mount Sinai Medical Center, New York, in prep.). $\alpha \mathrm{MyoD}$ 1, but not the control antibody $6 \mathrm{Fl}$, eliminated the major DNA-protein complexes formed with $\mathrm{C} 2$ cell nuclear extracts (compare bands indicated by filled circles in lanes 7 and 8). Neither antibody affected the nonspecific protein-DNA complexes formed with HeLa cell nuclear extracts (lanes 3 and 4).

These data suggest that one or more nuclear proteins that share antigenicity with $\mathrm{MyoD}$ are present in $\mathrm{C} 2$ muscle cells but not in HeLa cells and bind to the MyoD binding site we identified by use of the bacterial fusion protein. The inhibition of MyoDl binding by $\alpha$ MyoD1 monoclonal antibody in a GEMS assay has been observed by others (A. Lassar and S. Kohtz, pers. comm.). Because oligonucleotides often form multiple complexes in retardation gels, even with purified binding proteins, it is not clear whether the multiplicity of protein-DNA complexes we observed with $\mathrm{C} 2$ cell nuclear extracts represents more than one MyoD-related binding protein.

To define the nucleotides involved in the HCAMyoD1 interaction we used a synthetic DNA oligonucleotide spanning HCA nucleotides -70 to -40 and the glutathione-MyoD1 fusion product in methylation interference assays. Both sense and antisense DNA strands were investigated and, as shown in Figure 4, A and B, the methylation of two guanine residues at positions -56 and -49 on the antisense strand and of a guanine at po- 


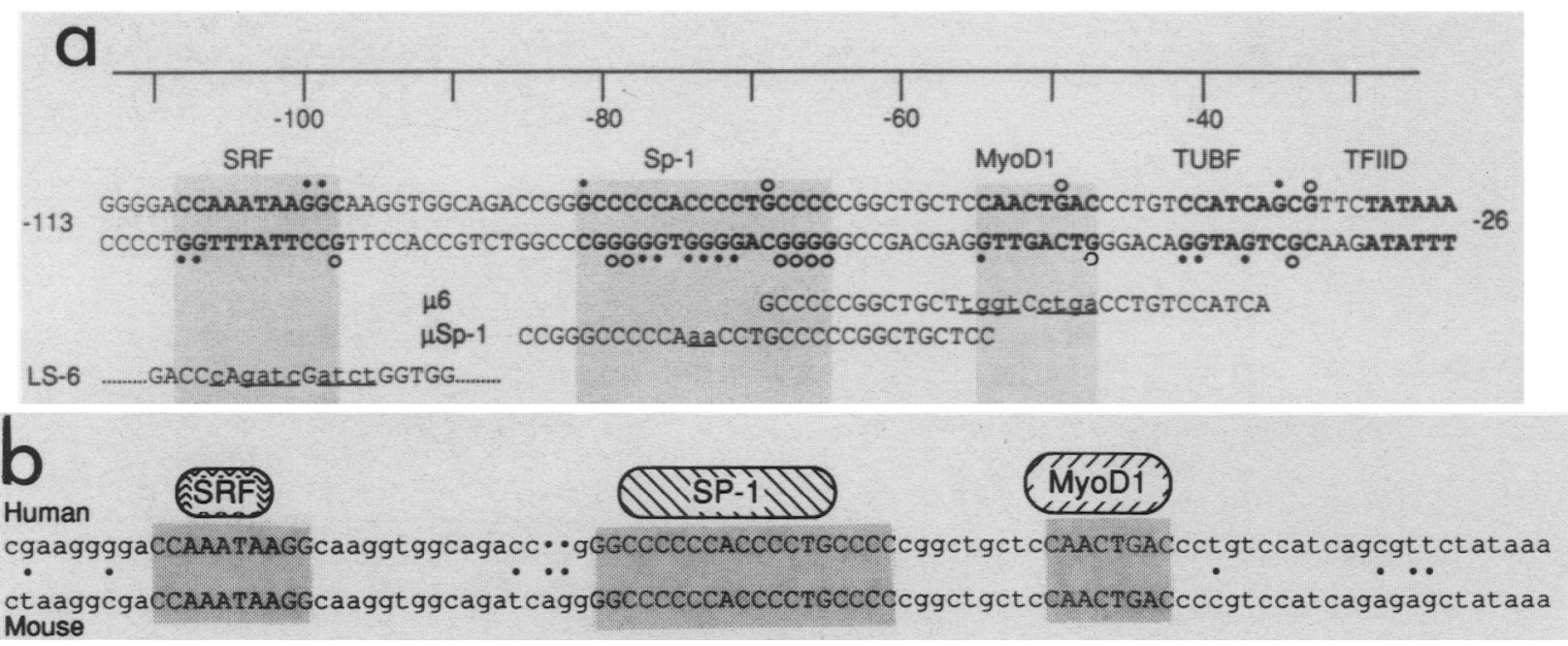

Figure 2. The HCA gene proximal promoter nucleotide sequences, nuclear protein-DNA interaction sites, mutations and comparison of the human and mouse sequences. $\{a \mid$ The nucleotide sequence of the HCA gene from -26 to -113 . Boldface nucleotides and shaded areas indicate the locations of the binding domains for the transcriptional regulators, SRF, Spl, and MyoDl; TUBF and the TATA box-binding TFIID. Circles above and below some bases represent sites of complete $(O)$ and partial $(O)$ interference with factor binding, as determined by guanine methylation interference experiments (Gustafson and Kedes 1989) [SRF, Sp1, and TUBF; and this work (MyoD1)]. The sequences of the coding strand of SRF-, Sp1-, and MyoDl-binding site mutations (LS-6, $\mu$ Spl, and $\mu 6$, respectively) are shown below the wild-type sequence. Mutated bases are shown in underlined lowercase. $(b \mid$. Nucleotide sequence comparison (coding strand) of the human (Minty and Kedes 1986) and mouse HCA sequences (Garner et al. 1986). Capitalized, shaded base pairs represent the location in the human sequence and the putative locations in the mouse sequence of the transcription regulatory factors SRF, Spl, and MyoDl. The two dots just upstream of the human Spl site represent the minimal gap required to maintain colinearity of the two sequences for comparative purposes. Dots between the two sequences are located at the mismatches.

sition -51 on the sense strand interfered with the MyoD1 protein binding.

Densitometric scanning (data not shown) confirmed strong interference of the antisense guanine at position -56 , weak interference of the guanine at -49 and weak interference of the guanine on the sense strand at -51 . No additional guanine methylation appeared to interfere with binding of the fusion protein. This region contains a hexameric sequence (CANNTG) (see Fig. 2) that has been proposed as the core MyoDl-binding sequence in the mouse MCK gene (Lassar et al. 1989). Interestingly, a GCTGC motif involved in the MyoD1-MCK interaction and located $3^{\prime}$ with respect to the CANNTG sequence (Lassar et al. 1989) is located 5' to the HCA interaction site but apparently does not participate in the MyoDl binding to the HCA gene.

The trans-activation induced by the MyoD1 protein in nonmyogenic cell lines requires at least three intact regulatory modules in the HCA promoter

To test whether MyoDl activates transcription by binding to the HCA promoter, several promoter mutants were generated by introduction of site-specific mutations at or adjacent to the nucleotides shown to interact with the MyoDl protein. Because previous experiments (Gustafson and Kedes 1989; T. Miwa, unpubl.) suggested that the transcriptional activator $\mathrm{Spl}$ may participate in regulating cardiac $\alpha$-actin gene expression, we assessed the functional role of an Sp1 binding site located at -70 , just upstream from the MyoDl binding site (Gustafson and Kedes 1989) by constructing a mutant at this site as well. The relevant sequences of SRF, Spl, and MyoD1 site mutants are shown in Figure 2A. As demonstrated previously, the LS-6 mutant (Miwa and Kedes 1987) fails to bind SRF or a related protein and does not compete for its binding (Gustafson et al. 1988). The HCA $-70 /-47$ 46 MyoD1-site mutant does not compete for MyoD1 binding to the nonmutated promoter (Fig. 5A) and does not complex with the protein (data not shown). Similarly the HCA oligomer $-87 /-65 \mu \mathrm{Spl}$ mutant (see Methods/ does not compete for $\mathrm{Sp} 1$ binding to the HCA $-87 /-65$ oligonucleotide (Fig. 5B), but does compete for MyoDl binding (data not shown) and the nonmutated DNA self-competes for Spl binding (Fig. 5B, lane 3) (Gustafson and Kedes 1989). The appearance of a doublet when purified $\mathrm{Spl}$ binds in the GEMS assay has been described previously (Dawson et al. 1988; Gustafson and Kedes 1989).

The HCA mutants HCAl77 $\mu 6-\mathrm{CAT}, \mathrm{HCA} 177 \mu$ Sp1CAT, and LS6 (HCA177CAT with mutations in the CArG element/ were cotransfected into CV-1 cells with the MyoD1 cDNA expression vector. The mutants $\mu 6$ and $\mu$ Spl (Fig. 6A) and LS6 (data not shown) showed little or no transcriptional induction by the MyoDl suggesting that trans-activation by MyoDl correlates not only with an intact MyoDl binding site but also with intact binding sites for $\mathrm{Spl}$ and $\mathrm{CArG}$ binding factor.

Intact binding sites for $M y o D, S p 1$, and SRF are indispensable for HCA activation in myogenic cell lines

Additional muscle-specific factors that are not required for in vitro DNA-protein interaction, may be 


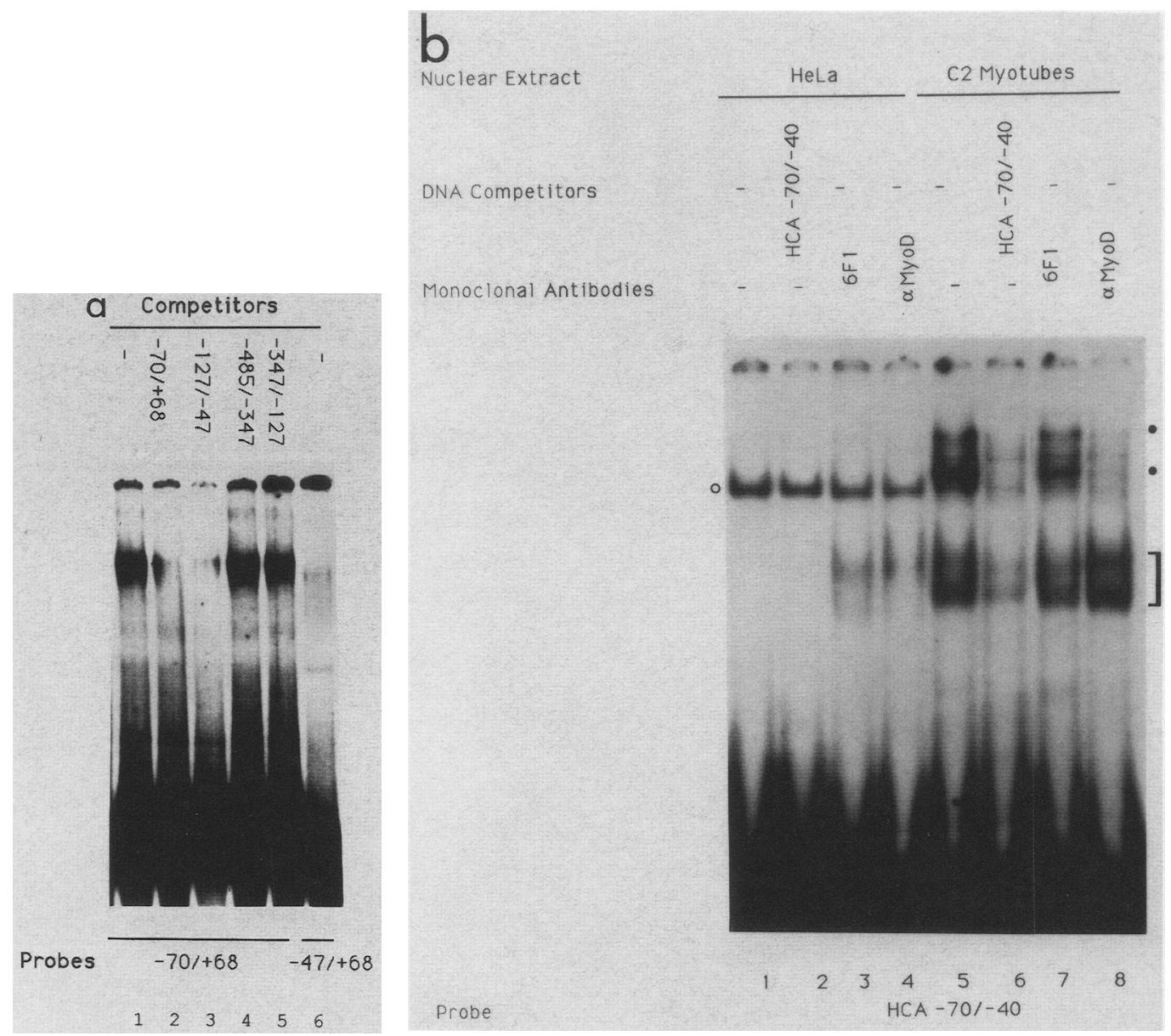

Figure 3. The glutathione-MyoDl fusion protein and factors present in $\mathrm{C} 2$ cell line nuclear extracts bind the HCA promoter. (a) The glutathione-MyoD1 fusion protein $(0.1 \mu \mathrm{g})$ was incubated with the end-labeled $-70 /+68 \mathrm{HCA}$ fragment $($ lane 1$)$. Poly[d(I-C) $(0.1 \mu \mathrm{g})$ was added to each reaction as nonspecific competitor. A 100-fold molar excess of various unlabeled HCA DNA fragments spanning the whole promoter region from -485 to +68 was employed as competitor (lanes 2-5). The glutathione-MyoD1 protein complex formation is shown by the appearance of a major shifted band in the gel mobility-shift assay. In lane 6 , the HCA fragment $-47 /+68$ was analyzed for protein interaction. (b) The same end-labeled HCA oligomer employed in $a$ was used in GEMS assays with nuclear extracts from either HeLa cells (lanes 1-4) or C2 myotubes (lanes 5-8). All lanes in the photograph were run on the same gel. The monoclonal antibodies $6 \mathrm{Fl}$ and $\alpha \mathrm{MyoD}$ (lanes 3, 4, 7, and 8) were preincubated with the nuclear extracts before adding the end-labeled HCA $-70 /-40$ probe. A 50-fold molar excess of nonlabeled HCA $-70 /-40$ (lanes 2 and 6) served as DNA competitor. (O) Nonspecific retarded band detected apparently only with the HeLa cell extract; $(0)$ specific shifted complexes formed when nuclear extract from C2 myotubes was employed; (bracket) complexes that were unaffected by the presence of $\alpha$ MyoD antibody. After electrophoresis, the gels were dried and autoradiographed over night.

required for MyoDl to promote HCA gene expression in vivo. Lack of such factors in the "nonphysiological" nonmuscle environment of $\mathrm{CV}-1$ could be responsible for the failure of MyoDl to trans-activate the HCA mutants. To distinguish this possibility, different HCA promoter-CAT constructs including $\mu 6$ and $\mu \mathrm{Spl}$ were transiently transfected in the myogenic $\mathrm{C} 2$ cell line and assayed for expression. The lack of expression by the Sp1 and MyoDl binding site mutants is consistent with the result in CV-1 cells (Fig. 6B). Relative to the activity of the wild-type HCA177CAT promoter, HCA177 $\mu 6$-CAT and HCA177 $\mu$ Spl-CAT expressed at $3 \%$ and $23 \%$, respectively. The LS6 mutant (HCA177 $\mu$ CArG-CAT) has been shown previously (Miwa and Kedes 1987) to express at $12 \%$ wild type. Taken together, these results suggest that the MyoDl gene product and its intact target element are required for the expression of the cardiac $\alpha$-actin gene promoter. Furthermore, muscle-specific expression does not appear to require either the presence of other muscle-specific auxiliary factors or tissue-specific isoforms or modifications of the CArG binding factor. It does however appear to require unaltered elements for CArG binding factor and Sp1.

The HCA transcription is reconstituted in Drosophila melanogaster cells on complementation with MyoD1 and $S p 1$

We tested the functional activity of the promoters and the transcription regulatory proteins in the Schneider 


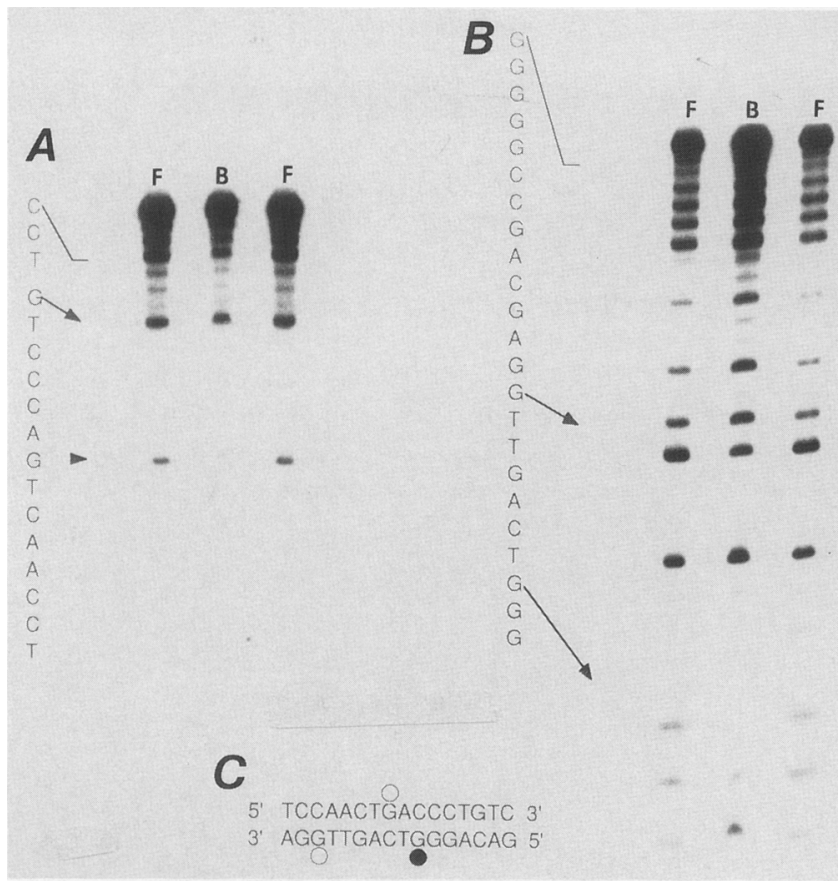

Figure 4. Methylation interference footprinting of the MyoDl protein on the HCA promoter. The coding $(A)$ and noncoding $(B)$ strands of an oligonucleotide representing the $-70 /-40$ HCA promoter region were methylated partially and analyzed after binding with the glutathione-MyoDl protein. $(\mathrm{F}$ and $\mathrm{B})$ Free and bound probes, respectively. Analysis included densitometric scanning of the autoradiographs (data not shown). The coding strand shows a single, partially interfered guanine residue (arrowhead in $A$ ). The noncoding strand shows one complete and one incomplete guanine interference residue (arrows in $B$. In $B$, twice as many decays per minute were applied in the bound probe lane $(B)$ such that the degree of interference should be judged by comparing the intensity of bands above and below the contacted nucleotide as well as between the different lanes. (C) Summary of the methylation footprint data. $(O \mid$ Partial interference; $(0 \mid$ strong interference.

cell line derived from the $D$. melanogaster embryos, which are devoid of many mammalian transcriptional activator homologs including Spl /Courey and Tiian 1988; Santoro et al. 1988). Preliminary experiments established that the Moloney sarcoma virus (MSV) LTR segment driving MyoDl expression in the LTR-MyoDl construct was active in Schneider cells (data not shown).

Accordingly, we transfected Schneider cells with pHCA177-CAT and with either or both the LTRMyoDl expression vector and the plasmid pPAcSpl. pPAcSpl carries the Drosophila nonmuscle actin gene promoter driving human Spl cDNA transcription (Courey and Tjian 1988). As demonstrated in the results presented in Figure 7A, Spl and MyoDl are required for transcription and have a synergistic effect (24-fold). The LTR-MyoD1 vector alone has no effect on HCA177CAT expression; the pPAcSpl plasmid alone engenders but weak expression (less than twofold over its effect on the HCA177 $\mu$ Sp1-CAT mutant). To demonstrate further the requirement of the CArG binding factor, Spl, and
MyoD1 in activating the HCA transcription, the LS6, HCA177 $\mu 6$-CAT and HCA177 $\mu$ Spl-CAT mutants were cotransfected in Schneider cells with different combinations of Spl and MyoD1 expression vectors (Fig. 7B). The results of these experiments reveal that $\mathrm{Spl}$, the CArG binding factor, and the tissue-specific factor MyoDl are all simultaneously required for expression of the HCA gene. Several constructs showed low level (two- to fourfold) increases of expression in the presence of exogenously supplied $\mathrm{Spl}$ alone (Fig. 7). Although these effects remain unexplained, we note that they were not observed in every construct or in the presence of combinations of exogenously supplied Spl and MyoDl.

\section{Discussion}

Here, we report that the MyoD1, Spl, and SRF or SRFrelated proteins bind specifically to the human cardiac $\alpha$-actin gene promoter and are involved in its activation. The organization of the proximal promoter of the HCA gene is summarized in Figure 2A. The mechanisms by which the muscle determinant factors of the MyoDl family (Davis et al. 1987) activate expression of musclespecific genes are not well understood. The muscle creatine kinase $(\mathrm{MCK})$ gene and the human cardiac actin gene are apparently activated by the MyoDl product (Lassar et al. 1989) (and this work) but it is not clear how other genes interact with MyoDl. For example, a chicken congener of MyoDl, CMDl, promotes transcription of the chicken skeletal $\alpha$-actin gene land the myosin light chain $1 / 3$ gene (Lin et al. 1989)], but neither MyoDl fusion protein (Lassar et al. 1989) nor in vitro translation products (Lin et al. 1989) appear to bind to the skeletal $\alpha$-actin DNA. We have not investigated the role of other members of the MyoDl muscle-determinant gene family, such as myogenin (Wright et al. 1989) and Myf5 (Braun et al. 1989) in activating HCA gene expression. These two myogenic determinant gene products have been shown recently to interact with the same DNA sequence recognized by $\mathrm{MyoDl}$ (Braun et al. 1990; Brennan and Olson 1990). Nevertheless, it is unlikely that myogenin is involved directly in the effects we observe in CV-1 cells because CV-1 cells stably expressing transfected MyoDl fail to activate the endogenous myogenin gene (A. Lassar, pers. comm.).

The MyoDl product belongs to a super-family of proteins having in common an amphipathic helix-loophelix domain (Murre et al. 1989a; Kingston 1990). Among those proteins are the product of the proto-oncogene c-myc (Alitalo et al. 1983), the lyl-1 gene product (Mellentin et al. 1989), the $\kappa$ enhancer-binding proteins E12 and E47 (Murre et al. 1989a,b), the immunoglobulin enhancer-binding protein TFE3 (Beckman et al. 1990) and the products of the Drosophila genes daughterless (Caudy et al. 1988a,b), twist (Thisse et al. 1988), enhancer of split (Klaembt et al. 1989), and achaete-scute T4/T5 (Alonso and Cabrera 1988). The MyoDl protein can form heterodimers in vitro with the E12 protein (Murre et al. 1989b), and heterodimerization of MyoD1 and E12 or related proteins takes place also in vivo 


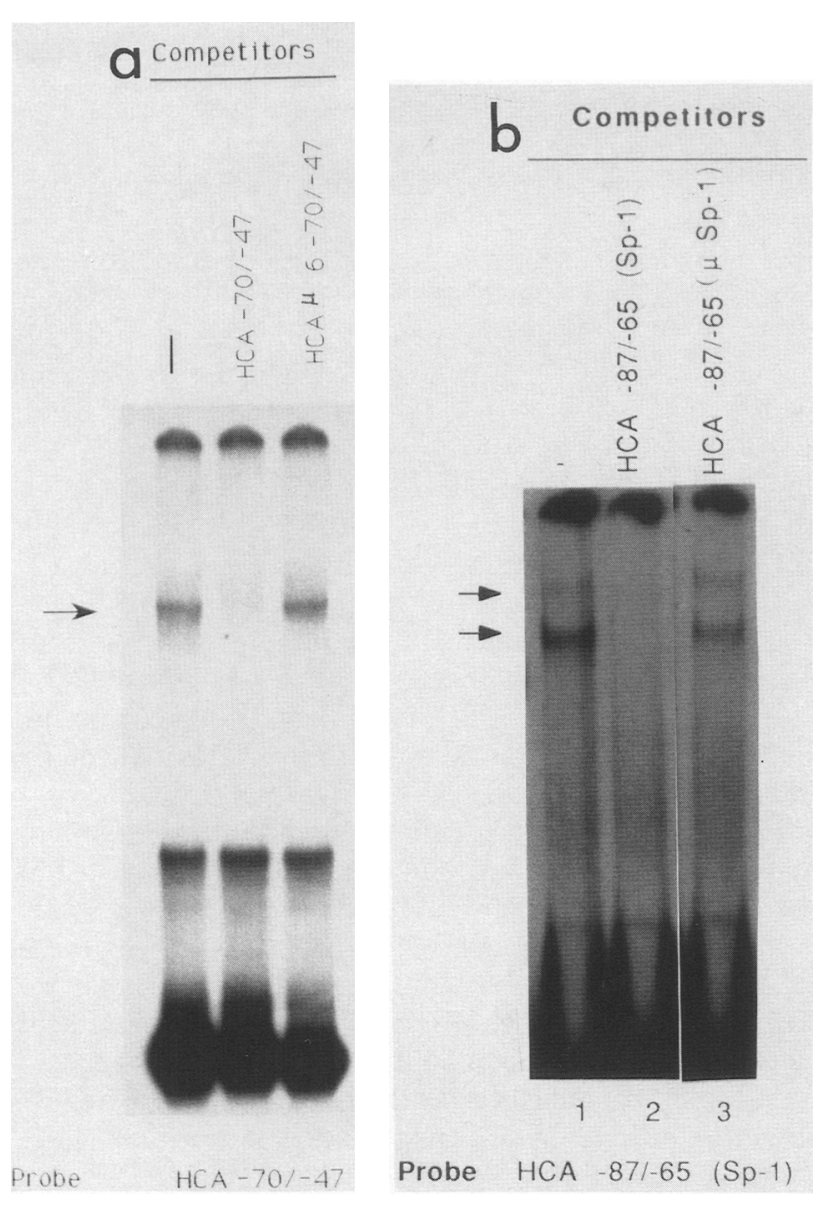

Figure 5. The HCA mutant $\mu 6$ does not bind MyoDl and base changes in the Spl site of the HCA $-87 /-65$ oligomer prevent binding of Spl. (a) The HCA $\mu 6$ mutant (see Fig. 2a) was assayed for its binding property by use of GEMS assay with purified glutathione-MyoD1 fusion protein. (Lane 1) The end-labeled HCA $-70 /-47$ oligonucleotide, incubated with glutathioneMyoD1 protein, generated a complex visible as a shifted band. A 50 -fold molar excess of unlabeled HCA $-70 /-47$ (lane 2) or $\mathrm{HCA}-70 /-47 \mu 6$ (lane 3) oligonucleotides were included in the protein-DNA binding reaction. $(b)$ The end-labeled HCA $-87 /-65$ oligomer $(0.1 \mathrm{ng})$ was incubated with homogeneously purified Sp1 (1 ng) and analyzed by use of GEMS assay (lane 1). The arrows point to the two shifted complexes. Competition experiments were performed adding a 50-fold molar excess of either unlabeled HCA $-87 /-65$ (wild type, lane 2) or HCA $-87 /-65 \mu \mathrm{Spl}$ (lane 3) oligonucleotides. The figure is an autoradiograph of the dried GEMS assays.

(Davis et al. 1990). These findings, along with the ubiquitous expression of E12 (Murre et al. 1989b), the increased affinity of MyoD1/E12 heterodimers versus homodimers for specific DNA interaction, and the indirect evidence for a biological activity of the MyoDl-E12 complex in vivo (Davis et al. 1990), support the hypothesis that the combination of MyoDl and E12 is critical for activation for the myogenic program. Heterodimerization has been reported also for other transcription regulatory factors (Chiu et al. 1988; Curran and Franza
1988; Halozonetis et al. 1988; Kouzarides and Ziff 1988; Nakabeppu et al. 1988; Rauscher et al. 1988) and usually increases the affinity of the heterodimer complex for the DNA.

Binding of MyoD1 alone (Lassar et al. 1989) or MyoD1-E12 complexes (Murre et al. 1989b) to DNA requires a defined nucleotide sequence. The CANNTG motif is the minimal region in the MCK enhancer recognized by the MyoD1, MyoDl/E12, and MEF 1 factors (Buskin and Hauschka 1989) and is present (Donoghue et al. 1988) in the MyoDl responsive enhancer of the mouse MLC 1/3 gene (Lin et al. 1989). An identical, and functional, consensus element lies at the core of the MyoD1 binding site in the HCA promoter. Abolition of the consensus CANNTG sequence prevented MyoD1

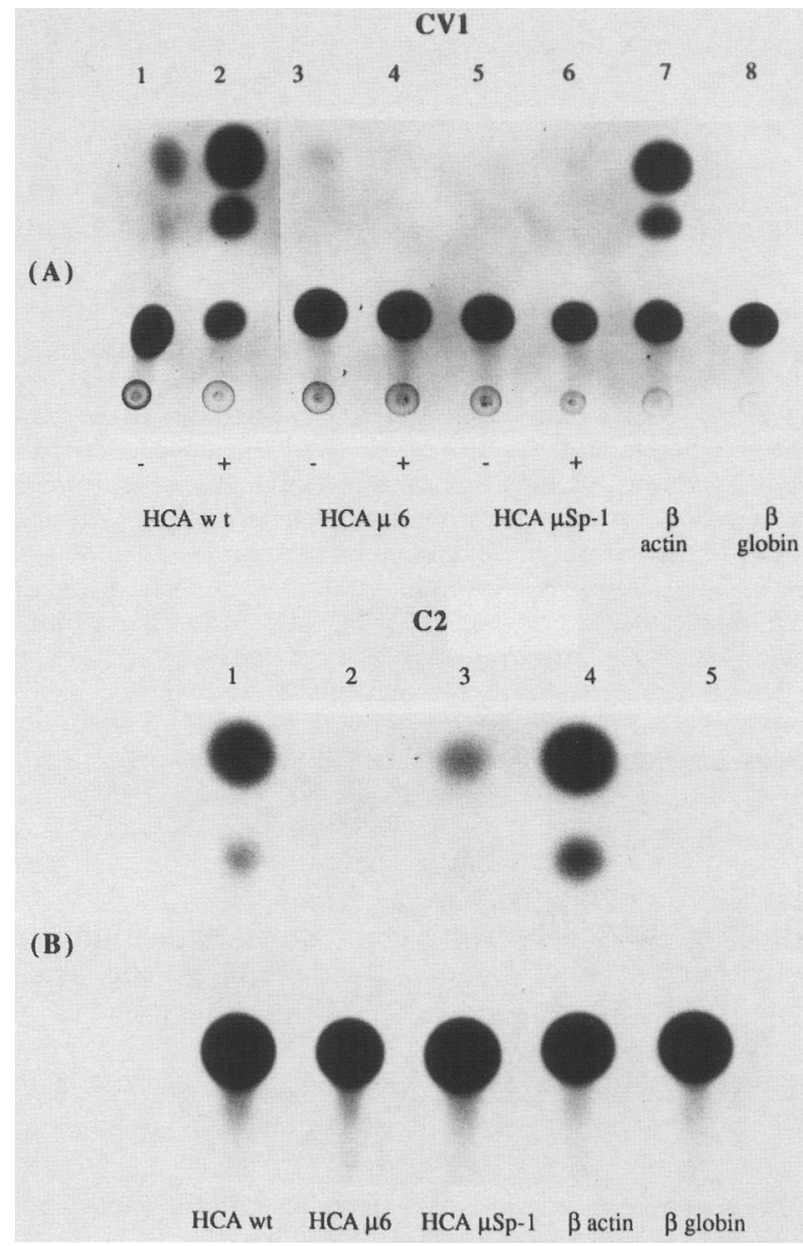

Figure 6. The HCA $\mu 6$ and $\mu \mathrm{Spl}$ mutations no longer function as promoters and cannot respond to MyoDl. (A) Various chimeric plasmid constructs $(5 \mu \mathrm{g}$ each) were transfected in the absence $(-)$ or presence $(+)$ of $1 \mu \mathrm{g}$ of the LTR-MyoD1 expression vector in the CV-1 cell line: (lanes 1 and 2) HCA177

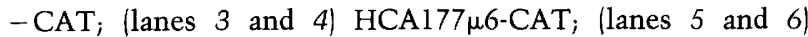
HCA177 $\mu$ Spl-CAT. (B) HCA177-CAT $(5 \mu \mathrm{g})$ (lane 1), HCA177 $\mu 6$-CAT (lane 2), HCAl77 $\mu$ Spl-CAT (lane 3), $\beta$-actinCAT (lane 4) and $\beta$-globin CAT (lane 5) were transfected into the $\mathrm{C} 2$ myogenic cell line. After $48 \mathrm{hr}$, the cells were harvested and the CAT assay performed as described in Methods. 


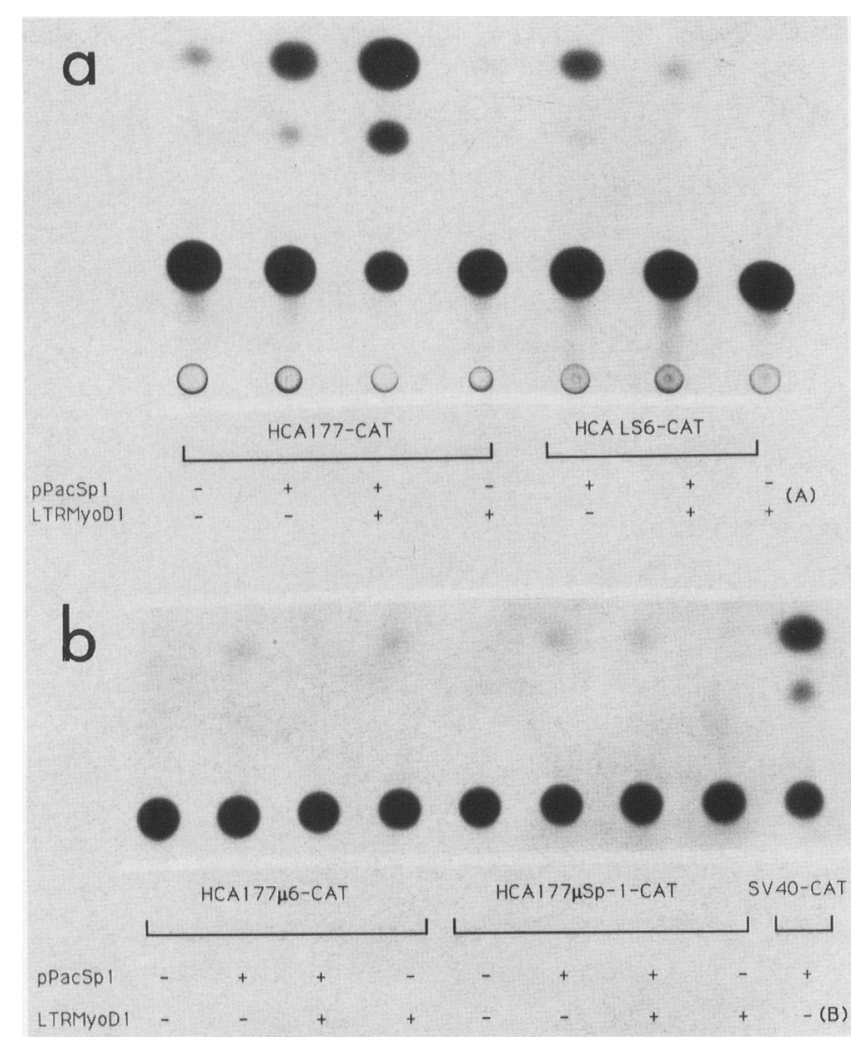

Figure 7. Drosophila Schneider cells express the HCA gene when complemented with exogenously introduced Spl and MyoDl. Various CAT expression vectors (5 $\mu \mathrm{g}$ each) were transfected into Drosophila embryo Schneider cells in the absence (-) or presence of different combinations of the pPAcSpl and LTR-MyoDI expression vectors as indicated in the figure. (a) pHCA177-CAT or pHCA177-LS6-CAT. (b) pHCA177 $\mu 6$ CAT, pHCA1 $77 \mu$ Spl-CAT, or pSV40-CAT. pSV40-CAT is inactive in the absence of Spl (Courey and Tjian 1988). The cells were harvested after $48 \mathrm{hr}$ and assayed for CAT activity as described in Methods.

binding and eliminated the functional response of the promoter to $\mathrm{MyoDl}$ protein. The HCA promoter is strongly trans-activated when cotransfected with a MyoD1 cDNA expression vector in both CV-1 and HeLa cells. This is in contrast to the observations that neither CV-1 nor HeLa cells support efficent trans-activation of the MCK or the chicken cardiac $\alpha$-actin promoters (Lin et al. 1989; Weintraub et al. 1989). These experiments are consistent with a model for HCA promoter expression in which MyoDl is the only required muscle specific protein. However it is not clear why HCA but neither MCK nor chick cardiac $\alpha$-actin promoter are transactivated by MyoDl or MyoDl-related factors in CV-1 (Lin et al. 1989; Weintraub et al. 1989). One possible explanation relies on different amounts of cotransfected plasmid employed by us and by others (Lin et al. 1989; Weintraub et al. 1989) and/or on different transfection protocols (Weintraub et al. 1989).

The HCA promoters containing the mutant sequences LS6, $\mu 6$, or $\mu$ Spl were not trans-activated by MyoD1 in either CV-1 or HeLa cells. The same mutant elements were totally inactive $(\mu 6)$ or showed only a vestigial inducibility (LS6 and $\mu$ Spl) when transfected in the C2 myogenic cell line. Because MyoDl does not interact either with the CArG motif at -100 or the Spl site at -75 (data not shown), we conclude that an SRF-related factor, $\mathrm{Spl}$, and MyoDl cooperate in insuring the tissuespecific transcription of the HCA gene and that the muscle-specific factor MyoDl by itself is not sufficient to do so. The results presented here confirm the hypothesis that the CArG box motif is a necessary element for the cardiac $\alpha$-actin transcription in concert with other cis-acting elements (Minty and Kedes 1986; Miwa and Kedes 1987; Phan-Dinh-Tuy et al. 1988; Mohun et al. 1989; Taylor et al. 1989; Webster and Kedes 19901, but make unlikely the possibility that the CArG box itself determines the tissue-specific expression of the human cardiac actin gene. That role appears to be reserved for MyoDl or a member of the MyoDl family.

Experiments using Schneider cells (Fig. 7) support the conclusion that the HCA expression can be induced by the simultaneous presence of Spl, MyoDl, and Drosophila SRF (Norman et al. 1988). In addition, the daughterless gene product, which appears to be a homolog of the mammalian E12 protein (Caudy et al. 1988a,b), may be playing a role in cooperation with $\mathrm{MyoDl}$ in these cells. The existence of both functional and positional relationships among the Spl, MyoDl, and SRF-related factor binding sites is supported strongly by the structural and sequence conservation within this region when the human (Minty and Kedes 1986) and mouse sequences (Garner et al. 1986) are compared (Fig. 2B). The sites are identical between the two species, and the whole promoter region is highly conserved. The few base mismatches that do occur cluster between the functional domains that we have defined. The pentameric GCTGC sequence associated with the MyoDl core consensus (see above) is also conserved. The cardiac $\alpha$-actin gene is strongly expressed in skeletal muscle during embryogenesis in man (Minty et al. 1986) and mouse (Minty et al. 1982). The gene is also coexpressed in adult human skeletal muscle (Gunning et al. 1983), in immortalized myogenic cell lines (Bains et al. 1984), and in human primary muscle cells (Minty et al. 1986).

As its name implies, the cardiac $\alpha$-actin mRNA is a prominent transcript in heart muscle but, as of this writing, no proteins or cDNAs homologous to MyoD1 have been reported in heart muscle at any stage of vertebrate development (Sassoon et al. 1989). Does the absolute reliance of HCA transcription on the presence of MyoD1 in skeletal muscle mean that the HCA gene must be subjected to an entirely different set of transcriptional controls in heart muscle? And that the MyoDl binding site is not a critical DNA regulatory element in the heart? It would seem possible, therefore, that a heart-specific regulatory factor, possibly analogous to MyoDl but sufficiently diverged so that it does not share easily detectable nucleotide sequences or epitopes, binds to the MyoDl element of the HCA promoter. Experiments of the kinds reported here but performed in cardiocytes and developing embryos can ad- 
dress these questions and unravel the mechanisms governing the disparate patterns of $\alpha$-actin gene expression during cell differentiation and development.

\section{Methods \\ Plasmids, site-directed mutagenesis, and synthetic oligonucleotides}

The HCA-CAT constructs employed have been described previously (Minty and Kedes 1986; Miwa and Kedes 1987). In brief, a promoterless plasmid was constructed consisting of the HindIII-BamHI restriction endonuclease fragment of pSV2CAT (Gorman et al. 1982) containing the bacterial chloramphenicol acetylase gene coupled to the SV40 small t intron and early region polyadenylation signals. This DNA fragment was inserted in pBR322 to create pHCA0CAT. A DNA segment of the human cardiac actin gene from -177 bp from the start of transcription (EcoRI restriction endonuclease linker end) to +68 (HindIII restriction endonuclease linker end) was used to replace the EcoRI-HindIII fragment of pHCAOCAT to create pHCA177CAT. Gel retardation assays and methylation interference footprinting studies have defined seven sites of binding by nuclear proteins. These seven binding sites are: CArG box 2 at -160 , a site for binding of CBF2 (Gustafson and Kedes 1989), which is distinct from that of SRF; CArG box 1, a site for SRF binding at -100 (Gustafson et al. 1988; Miwa et al. 1987); three Spl sites at $-80,+20$, and +33 ; the site for TATA-box upstream binding factor (TUBF) at -40 , that binds just upstream of the TATA box and is otherwise uncharacterized (Gustafson and Kedes 1989); and a MyoD1 binding site at -50 (this work). In addition the TATA box presumably is the site for interaction with the constitutive transcription initiation complex but this has not been evaluated directly in the cardiac actin promoter. The sequences and binding sites critical to this study are diagrammed in Figure 2.

Mutations in a number of these binding sites were created. Mutation of CArG box 1, LS6 has been described elsewhere (Miwa and Kedes 1987). Specific mutations in the MyoDI binding site, $\mu 6$, and the mutation of the Spl site at $-80, \mu S p 1$, were generated by use of the polymerase chain reaction (PCR) (Higuchi et al. 1988). Briefly, different synthetic oligonucleotides complementary to the HCA wild-type promoter sequence except for the base substitutions to be introduced and an oligomer complementary to the CAT gene were annealed, after heat denaturation, to $\mathrm{pHCA} 177 \mathrm{CAT}$. Taq polymerase-mediated elongation in the presence of dATP, dGTP, dCTP, dTTP and heat denaturation of the PCR products were performed for a total of 25 cycles using the DNA Thermal Cycler (Perkin Elmer Cetus). The PCR products were cleaved with restriction endonucleases ApaI and HindIII and were used to replace the unique ApaI-HindIII fragment in the promoter. The resulting plasmids were designated as pHCA177 $\mu 6-\mathrm{CAT}$ and $\mathrm{pHCA} 177 \mu \mathrm{Sp} 1-\mathrm{CAT}$. The integrity of the base substitutions was verified by DNA sequencing of each construct. The sequences of the coding strand of the oligomers employed in the methylation interference assays and for site-directed mutagenesis are shown below. The Spl and MyoDl binding sites are shown in shaded boxes; mutated bases are shown in underlined lowercase:

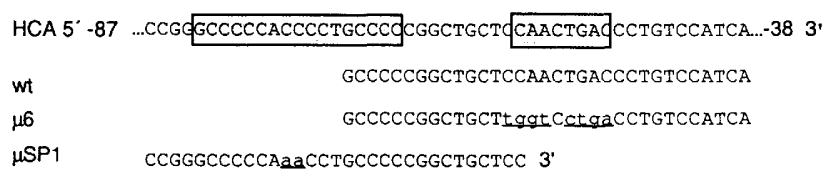

The sequence of the oligomer complementary to the CAT gene is: $5^{\prime}$-GTGACCTATGGTGGC-3'

The plasmids used in transfection experiments were purified by an alkaline lysis and by two rounds of $\mathrm{CsCl}$ density gradient sedimentation in the presence of ethidium bromide (Maniatis et al. 1982). The LTR-MyoDl eukaryotic expression vector was a kind gift of Andrew Lassar and Harold Weintraub (Fred Hutchinson Cancer Center, Seattle, WA) and is described in Davis et al. (1987). The plasmid pPAcSpl was generously provided by Robert Tjian (Courey and Tjian 1988).

Production and purification of the glutathione-MyoD1 fusion protein

The bacterial vector expressing the glutathione-MyoDl fusion protein was provided by Andrew Lassar, and the purification of the protein from bacterial lysates was performed according to Lassar et al. (1989).

\section{GEMS and methylation interference assays}

DNA fragments and synthetic oligonucleotides used in GEMS assays were end-labeled with $\mathrm{T} 4$ polynucleotide kinase and $\left[\gamma^{-32} \mathrm{P}\right]$ ATP and purified by electrophoresis in a polyacrylamide gel. The binding reactions for the GEMS were performed in the presence of end-labeled DNA fragments or synthetic oligonucleotides $(6000 \mathrm{cpm})$, purified glutathione-MyoD1 fusion protein $(0.1 \mu \mathrm{g})$ with the poly[d(I-C)] $(0.1 \mu \mathrm{g})$ as nonspecific competitor. The binding buffer is described in Lassar et al. (1989). Purified $\mathrm{Sp} 1$ (kindly provided by R. Tjian) ( $1 \mathrm{ng}$ ) was employed in the GEMS assay with different synthetic oligonucleotides. The binding reactions containing Spl were carried out in $20 \mathrm{~mm}$ HEPES (pH 7.9), $1.5 \mathrm{~mm} \mathrm{MgCl}, 0.2 \mathrm{~mm}$ EDTA, $100 \mathrm{~mm} \mathrm{KCl}$, and $20 \%$ (vol/vol) glycerol. No nonspecific competitor was added. GEMS assays with HeLa and C2 myotubes nuclear extracts $(10 \mu \mathrm{g})$ were performed in the same buffer employed with purified Spl (see above) in the presence of the poly[d(I-C)] $(2 \mu \mathrm{g})$ and $0.1 \mathrm{ng}$ of end-labeled HCA-70/40 probe. The monoclonal antibodies 6F1 and $\alpha \mathrm{MyoDl}(2.5 \mu \mathrm{g}$ each) (a generous gift of Stave Kohtz, Mount Sinai Medical Center, NY) were preincubated at room temperature for $15 \mathrm{~min}$ with HeLa and $\mathrm{C} 2$ myotubes nuclear extracts before adding end-labeled DNA probe and continuing the reaction for an additional $15 \mathrm{~min}$. For the methylation interference assay, the end-labeled synthetic oligonucleotides $(200,000 \mathrm{cpm})$ were partially methylated (Sturm et al. 1987) prior to complex formation with purified glutathione MyoD1 fusion protein $(2 \mu \mathrm{g})$. The complexed and free DNA were localized on the gel by autoradiography, eluted, cleaved with $10 \%$ piperidine, dried twice, and analyzed by autoradiography of the samples after electrophoresis in $12 \%$ polyacrylamide gels containing $7 \mathrm{M}$ urea. Densitometric analyses of the autoradiographs were performed with an LKB Ultrascan laser densitometer.

\section{Cell culture, nuclear extracts, transfections, and CAT assays}

C2 myogenic cells (Yaffe and Saxel 1977a,b) were grown in Dulbecco's modified Eagle medium (DMEM) enriched with $20 \%$ fetal calf serum (FCS), with 2 mM Glutamine and differentiation was induced culturing confluent myoblasts in DMEM with $2 \%$ horse serum. Both $\mathrm{HeLa}$ and $\mathrm{CV}-\mathrm{l}$ cell lines were grown in DMEM with $10 \%$ FCS, 2 mM glutamine. Drosophila Schneider cells (Schneider 1972) were kindly provided by Deborah Johnson (University of Southern California) and were maintained at $25^{\circ} \mathrm{C}$ in Schneider medium (GIBCO) supplemented with $10 \%$ FCS in $25-\mathrm{ml}$ flasks and transferred to 
60 -mm plates $12 \mathrm{hr}$ before transfection. HeLa cell nuclear extracts were made according to the method of Dignam et al. (1983). C2 cells were harvested 5 days after induction of myogenic differentiation with DMEM containing $2 \%$ horse serum, and nuclear extracts were made according to Dignam et al. (1983) with additional protease inhibitors. Leupeptin $(2 \mu \mathrm{g} / \mathrm{ml})$, and aprotinin $(2 \mu \mathrm{g} / \mathrm{ml})$ were added to buffers A, C, and D. Sucrose $(10 \%)$ was included in buffer $C$. The extracts were aliquoted and stored at $-80^{\circ} \mathrm{C}$ in buffer $\mathrm{D}$.

DNA transfections by the calcium phosphate precipitation method were performed as described previously (Minty et al. 1986). The reporter constructs (HCA-CAT series) were transfected at concentrations of $5 \mu \mathrm{g}$ per dish, the LTR-MyoD1 expression vector at concentrations varying from 1 to $5 \mu \mathrm{g}$ and the pPAcSpl expression vector at $1 \mu \mathrm{g}$. The final DNA concentration was brought to $20 \mu \mathrm{g}$ per dish using pUC118 plasmid DNA. Transfected $\mathrm{C} 2$ cells were incubated for $24 \mathrm{hr}$ at $37^{\circ} \mathrm{C}$, $10 \% \mathrm{CO}_{2}$ in $20 \% \mathrm{FCS}, 2 \mathrm{~mm}$ glutamine. DNA was then removed and the cells switched to DMEM with $2 \%$ horse serum, $2 \mathrm{mM}$ glutamine to induce differentiation. HeLa and CV-l cells were transfected for $12 \mathrm{hr}$ at $37^{\circ} \mathrm{C}, 10 \% \mathrm{CO}_{2}$ in $10 \%$ FCS, $2 \mathrm{~mm}$ glutamine before removing the DNA and cultured for an additional $24 \mathrm{hr}$. Drosophila Schneider cells were transfected by use of the same procedure employed for the mammalian cells except that they were kept at $25^{\circ} \mathrm{C}$ and left in the presence of the DNA for $48 \mathrm{hr}$. The transfection experiments were repeated at least twice with two independent plasmid preparations. Cells were harvested and CAT assays were performed as described by Gorman et al. (1982). CAT assays were quantitated by excision of spots and counted in a liquid scintillation counter. Results are expressed as percent activity relative to that of the wildtype promoter CAT construct, pHCA177CAT. The variability between independently performed CAT assays was $<15 \%$ and usually $<5 \%$.

\section{Acknowledgments}

We are indebted to Peter Evans and Rachelle Markowitz for help with plasmid preps and cell culture. Andrew Lassar, Harold Weintraub, Stave Kohtz, and Robert Tjian provided critical biological materials. We are especially grateful to Andrew Lassar for encouragement, advice, and information in advance of publication and to him and Hal Weintraub for critical reading of early versions of this manuscript. George Muscat, Gus Gustafson, and Howard Prentice provided valuable suggestions. This work was funded by grants from the National Institutes of Health, the American Heart Association/Greater Los Angeles Affiliate, and the Muscular Dystrophy Association to L.K. V.S. is a fellow of the Muscular Dystrophy Association.

The publication costs of this article were defrayed in part by payment of page charges. This article must therefore be hereby marked "advertisement" in accordance with 18 USC section 1734 solely to indicate this fact.

\section{References}

Alitalo, K., G. Ramsay, J.M. Bishop, S. Ohlsson, W.W. Colby, and A.D. Levinson. 1983. Identification of nuclear proteins encoded by viral and myc oncogenes. Nature 306: 274-277.

Alonso, M.C. and C.V. Cabrera. 1988. The achaete-scute gene complex of Drosophila melanogaster comprises four homologous genes. $E M B O J$. 7: 716-720.

Andrisani, O.M., D.A. Pot, Z. Zhu, and J.E. Dixson. 1988. Three sequence-specific DNA-protein complexes are formed with the same promoter element essential for expression of the rat somatostatin gene. Mol. Cell. Biol. 8: 1947-1965.

Bains, W., P. Ponte, H. Blau, and L. Kedes. 1984. Cardiac actin is the major actin gene product in skeletal muscle cell differentiation in vitro. Mol. Cell. Biol. 4: 1449-1453.

Beckman, H., L.-K. Su, and T. Kadesch. 1990. TFE3: a helixloop-helix protein that activates transcription through the immunoglobin enhancer $\mu \mathrm{E} 3$ motif. Genes Dev. 4: 167179.

Boxer, L.M., T. Miwa, T.A. Gustafson, and L.H. Kedes. 1989a. Identification and characterization of a factor that binds to two human sarcomeric actin promoters. J. Biol. Chem. 264: 1284-1292.

Boxer, L.M., R. Prywes, R.G. Roeder, and L.H. Kedes. 1989b. The sarcomeric actin CArG binding factor is indistinguishable from the c-fos serum response factor. Mol. Cell. Biol. 9: $515-522$.

Braun, T., G. Buschhausen-Denker, E. Bober, E. Tannich, and H.H. Arnold. 1989. A novel human muscle factor related to but distinct from MyoDl induces myogenic conversion in 10T1/2 fibroblasts. $E M B O ~ J .8: 701-709$.

Braun, T., E. Bober, B. Winter, N. Rosenthal, and H.H. Arnold. 1990. Myf-6, a new member of the human gene family of myogenic determination factors: evidence for a gene cluster on chromosome 12. EMBO I. 9: 821-831.

Brennan, T.J. and E.N. Olson. 1990. Myogenin resides in the nucleus and acquires high affinity for a conserved enhancer element on heterodimerization. Genes Dev. 4: 582-595.

Buskin, J.N. and S.D. Hauschka. 1989. Identification of a myocyte nuclear factor that binds to the muscle-specific enhancer of the mouse creatine kinase gene. Mol. Cell. Biol. 9: $2627-2640$.

Caudy, M., E.H. Grell, C. Dambly-Chaudiere, A. Ghysen, L.Y. Jan, and Y.N. Jan. 1988a. The expression of three members of the achaete-scute complex correlates with neuroblasts segregation in Drosophila. Cell 50: 425-433.

Caudy, M., H. Vassin, M. Brand, R. Tuma, L.Y. Jan, and Y.N. Jan. 1988b. Daughterless, a gene essential for both neurogenesis and sex determination, has sequence similarities to myc and the achaete-scute complex. Genes Dev. 2: 843852.

Chiu, R., W.J. Boyle, J. Meek, T. Sneal, T. Hunter, and M. Karin. 1988. The c-Fos protein interacts with c-Jun/AP-1 to stimulate transcription of AP-1 responsive genes. Cell 54: 541552.

Courey, A.J. and R. Tjian. 1988. Analysis of Spl in vivo reveals multiple transcriptional domains, including a novel glutamine-rich activation motif. Cell 55: 887-898.

Curran, T. and B.R. Franza, Jr. 1988. Fos and Jun: the AP-1 connection. Cell 55: 395-397.

Davis, R.L., H. Weintraub, and A.B. Lassar. 1987. Expression of a single transfected cDNA converts fibroblasts to myoblasts. Cell 51: 987-1000.

Davis, R.L., P.-F. Cheng, A.B. Lassar, and H. Weintraub. 1990. The MyoD DNA binding domain contains a recognition code for muscle-specific gene activation. Cell 60: 733-746.

Dawson, P.A., S.L. Hofmann, D.R. van der Wethuysen, T.C. Sudhof, M.S. Brown, and J.L. Goldstein. 1988. Sterol-dependent repression of low density lipoprotein receptor promoter mediated by 16 bp sequence adjacent to binding site for transcription factor Sp1. J. Biol. Chem. 263: 3372-3379.

Dignam, J.D., R.M. Lebovitz, and R.G. Roeder. 1983. Accurate transcription initiation by RNA polymerase II in a soluble extract from isolated mammalian nuclei. Nucleic Acids Res. 11: $1475-1489$.

Donoghue, M., H. Ernst, B. Wentworth, B. Nadal-Ginard, and 
N. Rosenthal. 1988. A muscle-specific enhancer is located at the $3^{\prime}$ end of the myosin light-chain $1 / 3$ gene locus. Genes Dev. 2: $1779-1790$.

Garner, I., A.J. Minty, S. Alonso, P.J. Barton, and M.E. Buckingham. 1986. A 5 ' duplication of the alpha-cardiac actin gene in BALB/c mice is associated with abnormal levels of alpha-cardiac and alpha-skeletal actin mRNA in adult cardiac tissue. EMBO I. 5: 2559-2567.

Gill, G. and M. Ptashne. 1988. Negative effect of the transcriptional activator GAL4. Nature 334: 721-724.

Gorman, C.M., L.F. Moffat, and B.H. Howard. 1982. Recombinant genomes which express chloramphenicol acetyl transferase in mammalian cells. Mol. Cell. Biol. 2: 1044-1051.

Guarente, L. 1988. UASs and enhancers: Common mechanism of transcriptional activation in yeast and mammals. Cell 52: 303-305.

Gunning, P., P. Ponte, H. Blau, and L. Kedes. 1983. $\alpha$-skeletal and $\alpha$-cardiac actin genes are coexpressed in adult skeletal muscle and heart. Mol. Cell. Biol. 3: 1985-1995.

Gunning, P., E. Hardeman, R. Wade, P. Ponte, W. Bains, H. Blau, and L. Kedes. 1987. Differential patterns of transcript accumulation during human myogenesis. Mol. Cell. Biol. 7: 4100-4114.

Gustafson, T.A. and L.H. Kedes. 1989. Identification of multiple proteins which interact with functional regions of the human cardiac $\alpha$-actin promoter. Mol. Cell. Biol. 9: 32693283.

Gustafson, T.A., T. Miwa, L. Boxer, and L. Kedes. 1988. Interaction of nuclear proteins with muscle specific regulatory sequences of the human cardiac actin promoter. Mol. Cell. Biol. 7: 4100-4119.

Halozonetis, T.D., K. Georgopoulos, M.E. Greenberg, and P. Leder. 1988. c-jun dimerizes with itself and with c-fos, forming complexes of different DNA binding affinities. Cell 55: $917-924$.

Higuchi, R., B. Krummerl, and R. Saiki. 1988. A general method of in vitro preparation and specific mutagenesis of DNA fragments: study of protein and DNA interactions. Nucleic Acids Res. 10: 7351-7367.

Jones, N. 1990. Transcriptional regulation by dimerization: two sides to an incestuous relationship. Cell 61: 9-11.

Kingston, R.E. 1990. Transcription control and differentiation: the HLH family, c-myc and C/EBP. Curr. Opin. Cell Biol. 1: $1081-1087$.

Klaembt, C., E. Knust, K. Tietze, and J.A. Campos-Ortega. 1989. Closely related transcripts encoded by the neurogenic gene complex Enhancer of split of Drosophila melanogaster. EMBO I. 8: 203-211.

Kouzarides, T. and E. Ziff. 1988. The role of the leucine zipper in the fos-jun interaction. Nature 312: 646-651.

Lassar, A.B., J.N. Buskin, D. Lockshon, R.L. Davis, S. Apone, S.D. Hauschka, and H. Weintraub. 1989. MyoD is a sequence-specific DNA binding protein requiring a region of myc homology to bind to the muscle creatine kinase enhancer. Cell 58: 823-831.

Lin, Z.-Y., C.A. Dechesne, J. Eldridge, and B.M. Paterson. 1989. An avian muscle factor related to $\mathrm{MyoDl}$ activates musclespecific promoters in nonmuscle cells of different germlayer origin and in BrdU-treated myoblasts. Genes Dev. 3: $986-996$.

Maniatis, T., E. Fritsch, and J. Sambrook. 1982. Molecular cloning: A laboratory manual. Cold Spring Harbor Laboratory, Cold Spring Harbor, New York.

Mellentin, J.D., S.D. Smith, and M.L. Cleary. 1989. lyl-1, a novel gene altered by chromosomal translocation in $\mathrm{T}$ cell leukemia, codes for a protein with a helix-loop-helix DNA- binding motif. Cell 58: 77-83.

Meyer, M.-E., B. Gronemeyer, M.-T. Turcotte, D. Bocqel, H-T. Tasset, and P. Chambon. 1989. Steroid hormone receptors compete for factors that mediate their enhancer functions. Cell 57: 433-442.

Minty, A. and L. Kedes. 1986. Upstream regions of the human cardiac actin gene that modulate its transcription in muscle cells: presence of an evolutionarily conserved repeated motif. Mol. Cell. Biol. 6: 2125-2136.

Minty, A., S. Alonso, M. Caravatti, and M. Buckingham. 1982. A fetal skeletal muscle actin mRNA in the mouse and its identity with cardiac actin mRNA. Cell 30: 185-192.

Minty, A., H. Blau, and L. Kedes. 1986a. Two level regulation of cardiac actin gene transcription: Muscle specific modulating factors can accumulate before gene activation. Mol. Cell. Biol. 6: 2137-2148.

Minty, A.J., E. Hardeman, P. Gunning, W. Bains, and L. Kedes. 1986b. Molecular biology of muscle development. UCLA Symp. Mol. Cell. Biol. 29: 507-519. pp. 507-519.

Miwa, T. and L. Kedes. 1987. Duplicated CArG box domains have positive and mutually dependent regulatory roles in expression of the human cardiac actin gene. Mol. Cell. Biol. 7: 2803-2813

Miwa, T., L. Boxer, and L. Kedes. 1987. CArG boxes in the human cardiac $\alpha$-actin gene are core binding sites for positive trans-acting regulatory factors. Proc. Natl. Acad. Sci. 84: 6702-6706.

Mohun, T.J., M.V. Taylor, N. Garrett, and J.B. Gurdon. 1989. The CArG promoter sequence is necessary for muscle-specific transcription of the cardiac actin gene in Xenopus embryos. EMBO J. 8: 1153-1161.

Murre, C., P. Schonleber McCaw, H. Vaessin, M. Claudy, L.Y. Jan, Y.N. Jan, C.V. Cabrera, J.N. Buskin, S.D. Hauschka, A.B. Lassar, H. Weintraub, and D. Baltimore. 1989a. Interactions between heterologous helix-loop-helix proteins generate complexes that bind specifically to a common DNA sequence. Cell 58: 537-544.

Murre, C., P. Schonleber McCaw, and D. Baltimore. 1989b. A new DNA binding and dimerization motif in immunoglobulin enhancer binding, daughterless, MyoD, and Myc proteins. Cell 56: 777-783.

Nakabeppu, Y., K. Ryder, and D. Nathans. 1988. DNA binding activities of three murine jun proteins: Stimulation by fos. Cell 55: 907-915.

Norman, C., M. Runswick, R. Pollock, and R. Treisman. 1988. Isolation and properties of cDNA clones encoding SRF, a transcription factor that binds to the $c$-fos serum response element. Cell 55: 989-1003.

Phan-Dinh-Tuy, F., D. Tuil, F. Schweighoffer, C. Pinset, A. Kahn, and A. Minty. 1988. The CCAArGG box: a protein binding site common to transcription regulatory regions of the cardiac actin, c-fos, and interleukin-2 receptor genes. Eur. J. Biochem. 173: 507-515.

Pinney, D.F., S.H. Pearson-White, S.F. Konieczny, K.E. Latham, and C.P. Emerson. 1988. Myogenic lineage determination and differentiation: Evidence for a regulatory pathway. Cell 53: $781-793$.

Ptashne, M. 1988. How eukaryotic transcriptional activators work. Nature 135: 683-689.

Rauscher, F.J., P.J. Voulalas, B.R. Franza, and T. Curran. 1988. Fos and Jun bind cooperatively to the AP-1 site: Reconstruction in vitro. Genes Dev. 2: 2025-2061.

Santoro, C., N. Mermod, P.C. Andrews, and R. Tjian. 1988. A family of human CCAAT-box-binding proteins activate transcription and DNA replication: cloning and expression 
of multiple cDNAs. Nature 334: 218-224.

Sartorelli, V., K.A. Webster, A.B. Lassar, and L.H. Kedes. 1989. The MyoD1 gene product trans-activates and binds to the human cardiac $\alpha$-actin promoter. Sardinia Symposium on Advances in Biotechnology, Control of Gene Expression. 180 (Abstr.).

Sassoon, D.A., G. Lyons, W.E. Wright, V. Lin, A.B. Lassar, H. Weintraub, and M. Buckingham. 1989. Expression of two myogenic regulatory factors, myogenin and MyoDl during mouse embryogenesis. Nature 341: 303-307.

Schneider, I. 1972. Cell lines derived from late embryonic stages of Drosophila melanogaster. /. Embryol. Exp. Morphol. 27: 353-365.

Simmons, D.M., J.W. Voss, H.A. Ingraham, J.M. Holloway, R.S. Broide, M.G. Rosenfeld, and L.W. Swanson. 1990. Pituitary cell phenotypes involve cell-specific interactions with other classes of transcriptional factors. Genes Dev. 4: 695-711.

Sturm, R.T., T. Baumruker, B.R. Franza, and W. Herr. 1987. A $100-\mathrm{kD}$ Hela cell octamer binding protein (OBP100) interacts differently with two separate octomer-related sequences within the SV40 enhancer. Genes Dev. 1: 11471160.

Tanaka, M. and W. Herr. 1990. Differential transcriptional activation by Oct- 1 and Oct-2: interdependent activation domains induce Oct-2 phosphorylation. Cell 60: 375-386.

Taylor, M., R. Treisman, N. Garrett, and T. Mohun. 1989. Muscle-specific (CArG) and serum-responsive (SRE) promoter elements are functionally interchangeable in Xenopus embyros and mouse fibroblasts. Development 106: $67-78$.

Thisse, B., C. Stoetzel, C. Gorostiza-Thisse, and F. PerrinSchmitt. 1988. Sequence of the twist gene and nuclear localization of its protein in endomesodermal cells of early Drosophila embryos. EMBO I. 7: 2175-2183.

Walsh, K. 1989. Cross-binding of factors to functionally different promoter elements in c-fos and skeletal actin genes. Mol. Cell. Biol. 9: 2191-2201.

Webster, K.A. and L. Kedes. 1990. The c-Fos CRE conveys constitutive expression to a tissue specific promoter. Mol. Cell. Biol. 10: 2402-2406.

Weintraub, H., S.J. Tapscott, R.L. Davis, M.J. Thayer, M.A. Adam, A.B. Lassar, and A.D. Miller. 1989. Activation of muscle-specific genes in pigment, nerve, fat, liver, and fibroblast cell lines by forced expression of MyoD. Proc. Natl. Acad. Sci. 86: 5434-5438.

Wright, W.E., D.A. Sassoon, and V.K. Lin. 1989. Myogenin, a factor regulating myogenesis, has a domain homologous to MyoD. Cell 56: 607-617.

Yaffe, D. and O. Saxel. 1977. Serial passaging and differentiation of myogenic cells isolated from dystrophic mouse muscle. Nature 270: 725-727.

1977. A myogenic cell line with altered serum requirements for differentiation. Differentiation 7: 159-166. 


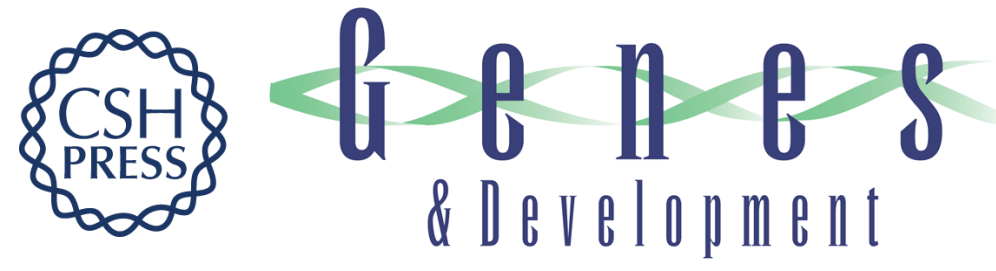

\section{Muscle-specific expression of the cardiac alpha-actin gene requires MyoD1, CArG-box binding factor, and Sp1.}

V Sartorelli, K A Webster and L Kedes

Genes Dev. 1990, 4:

Access the most recent version at doi:10.1101/gad.4.10.1811

References This article cites 68 articles, 25 of which can be accessed free at:

http://genesdev.cshlp.org/content/4/10/1811.full.html\#ref-list-1

License

Email Alerting

Service

Receive free email alerts when new articles cite this article - sign up in the box at the top right corner of the article or click here.

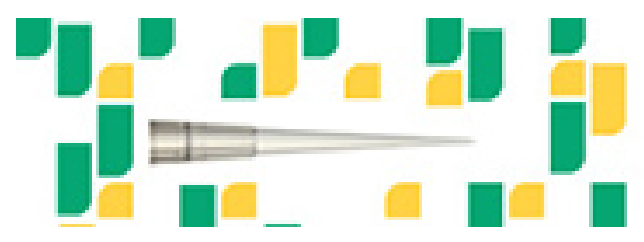

Focused on your science. 